\title{
Melketenner som biomarkører i epidemiologisk forskning
}

\author{
Helene Meyer Tvinnereim ${ }^{1}$, Maiken Rørvik Langseth ${ }^{2}$ og Kristin S. Klock ${ }^{3}$ \\ 1) Institutt for klinisk odontologi-Biomaterialer, Det medisinsk-odontologiske fakultet, Universitetet i Bergen \\ 2) stud. odont. ved Universitetet i Bergen 2006-2011 \\ 3) Institutt for klinisk odontologi - Samfunnsodontologi, Det medisinsk-odontologiske fakultet, Universitetet i Bergen \\ Korrespondanse: Helene Meyer Tvinnereim, Institutt for klinisk odontologi, Universitet i Bergen, Postboks 7800,5020 Bergen \\ E-post: Helene.Tvinnereim@iko.uib.no Telefon: +4755586258 Telefaks: +4755589862
}

\begin{abstract}
ENGLISH SUMMARY
Human primary teeth can give important information about trace element exposure prenatally and in early childhood - the period of tooth formation and the most vulnerable period in life. Trace elements from the environment and from nutrition are built into the tooth tissues during the period of tooth formation. As tooth tissues develop incrementally, according to a known pattern, and are very stable, teeth may function as recorders or biomarkers of different exposures during the period of tooth formation. In this paper the use of primary teeth as biomarkers of exposure is presented with a special focus on the use within epidemiology.
\end{abstract}

\section{INNLEDNING}

Melketenner kan gi viktig informasjon om eksponering overfor sporelementer på fosterstadiet og i tidlig barndom. Denne perioden av livet regnes for å være spesielt sensitiv med hensyn til eksponering for miljøgifter, fordi organene er umodne, og barrierene mot miljøet ikke er ferdigutviklet [1]. Fordi kroppen er i rask vekst, har barn generelt høyere metabolisme enn voksne og utsettes potensielt for større mengder forurensning per kilo kroppsvekt som en følge av høyere oksygenforbruk og større inntak av mat og drikke per kilo kroppsvekt [2]. Småbarn putter også gjerne ting i munnen som inneholder helsefarlige stoffer. En spesiell oppmerksomhet må derfor rettes mot barns miljøforhold.

Nye levesett og kostholdsvaner kan også virke inn på helsen. For lavt inntak av essensielle elementer fra ernæringen vil kunne gi helseutfall på kortere eller lengre sikt [3]. For å overvåke endringer i miljøet og befolkningens helsetilstand, kreves ulike kontrollrutiner. Enkelte vev og væsker i kroppen kan brukes til å måle kroppens opptak av elementer og forbindelser fra miljøet, såkalte biomarkører for eksponering [4]. Melketenner har vært brukt som biomarkører i en rekke studier og kan gi viktig informasjon om barnets miljø på fosterstadiet og i tidlig barndom [5-7]. Sporstoffer fra miljø og ernæring bygges inn i tannvevet etter hvert som tennene dannes. Fordi tannvevet dannes lagvis etter et kjent mønster og dessuten er svært stabilt, kan tenner fungere som en slags ferdsskriver for ulike eksponeringer i tanndanningsperioden $[8,9]$. Tannvev kan også vise morfologiske forandringer og mineraliseringsdefekter som resultat av eksponering overfor miljøgifter, sykdom eller ernæringssvikt i løpet av tanndannelsen $[10,11]$. Melketenner har vært brukt i en rekke epidemiologiske undersøkelser rundt om $i$ verden for å avdekke områder med miljøforurensning [12-15], undersøke hviken påvirkning eksponeringer for toksiske sporelementer har på barns utvikling og helse [1618] og for å kartlegge ernæringstilstanden hos grupper av barn $[7,19]$. I denne artikkelen presenteres hvordan melketenner har vært brukt og brukes i forskningssammenheng for å øke kunnskapen om barns opptak av toksiske og essensielle elementer fra miljø og ernæring, samt hvordan denne kunnskapen kan brukes til å forebygge helseskader.

\section{MELKETENNENES UTVIKLING}

Melketannsettet starter sin utvikling allerede i løpet av den andre måned av fosterstadiet [20]. I løpet av tredje til fjerde måned starter mineraliseringen av tannanleggene [21]. Ved ettårsalder er alle melketannskronene ferdig mineralisert, og ved tre til tre og et halvt års alder er også røttene ferdigdannet (Figur 1). Tennene vokser lagvis etter et kjent mønster og danner vekstlinjer $\mathrm{i}$ vevet som kan sammenlignes med årringene $\mathrm{i}$ en trestamme [9]. Både i emaljen og det underliggende dentinet finnes en karakteristisk vekstlinje, neonatallinje, som representerer endret metabolisme ved fødselen. Neonatallinjen i emalje er spesielt tydelig histologisk som en følge av endret konfigurasjon i emaljeprismene i denne perioden [22]. Lokalisasjon av neonatallinjen gjør det mulig å skille tannvev som er dannet pre- og postnatatalt (Figur 2). Det skjer en langsom dannelse av dentin (sekundærdentin) innerst mot pulpa gjennom hele tannens funksjonstid. Dette vevet representerer dermed en senere periode $\mathrm{i}$ barndommen frem mot tannfellingen [20]. Melketennene felles i løpet av barneårene og kan dermed gjøres tilgjengelige for forskningeprosjekter uten invasive ingrep. Tenner har en nærmest ubegrenset lagringstid når de oppbevares $\mathrm{i}$ tørr tilstand ved vanlig romtemperatur.

\section{BIOMARKØRER}

Begrepet biomarkør kan defineres som "målbare og kvantifiserbare biologiske parametere som fungerer som indekser for helse- og fysiologirelaterte vurderinger, for eksempel sykdomsrisiko, miljøeksponering og dens effekter, sykdomsdiagnose, epidemiologiske studier, etc" [23]. Man skiller gjerne mellom tre 


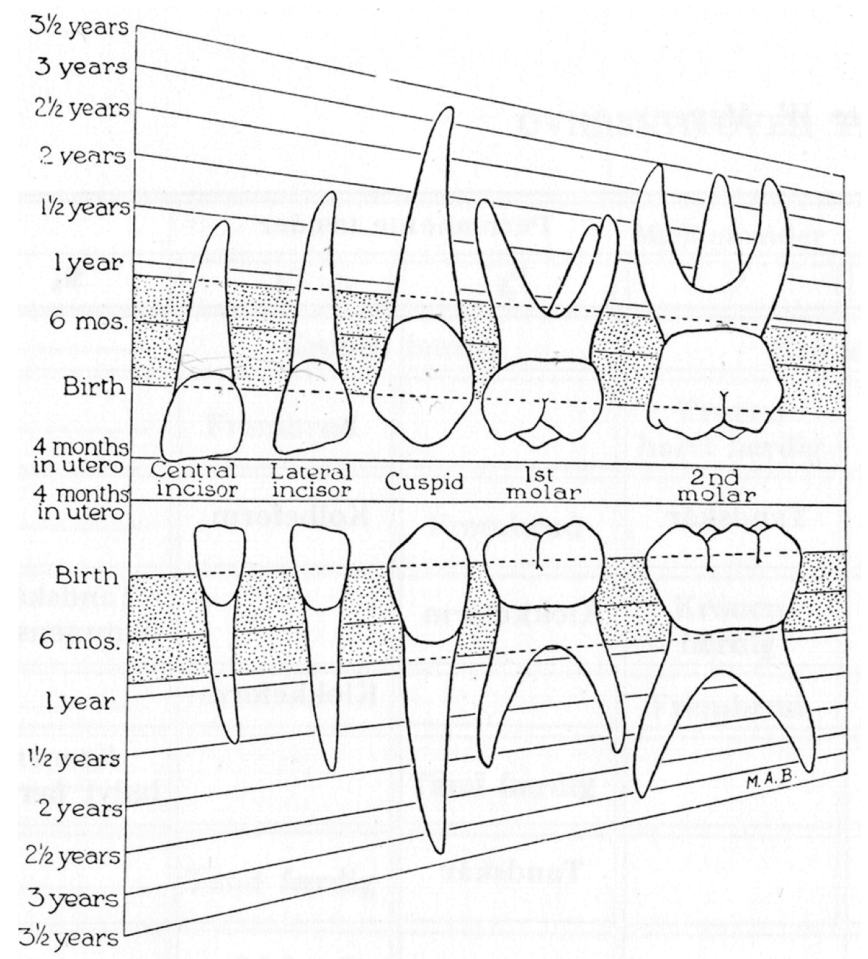

Figur 1. Illustrasjonen viser hvor stor del av melketennene som er mineralisert ved de angitte tidspunkt i kolonnen til venstre. [W. Krogh-Poulsen. Tændernes morfologi. København: Munksgaard, 1967] Figuren er trykket med tillatelse fra Munksgaard forlag.

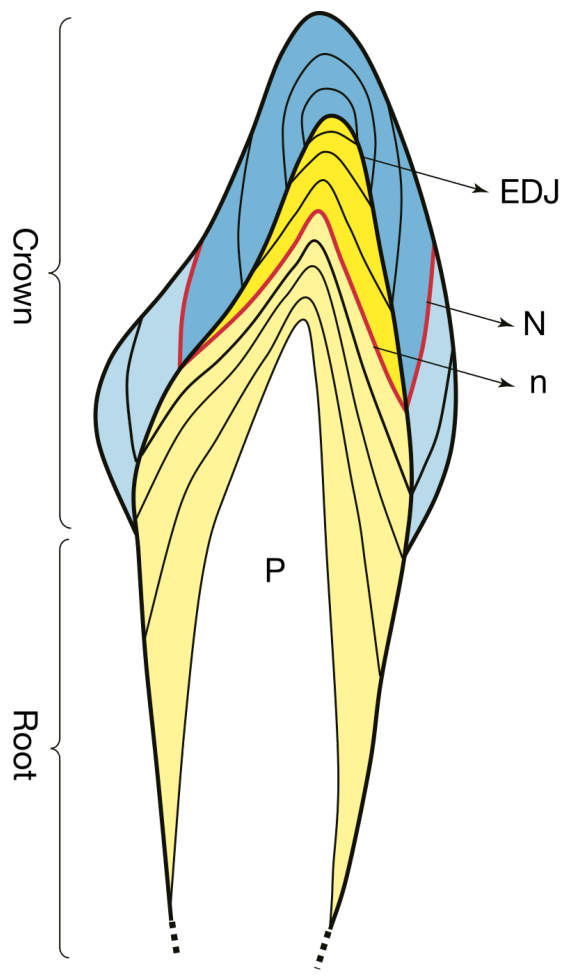

Figur 2. Illustrasion av longitudinelt snitt av en melketann $i$ utvikling. Vekstlinjer er markert i emalje (ytterste del av kronen) og i krone- og rotdentin (innerste del). Merk skillet mellom pre- og postnatal emalje og dentin markert ved neonatallinjen $(\mathrm{N}=$ neonatallinje $\mathrm{i}$ emalje, $\mathrm{n}=\mathrm{i}$ dentin). Prenatalt dannet emalje er mørkest farget på tegningen, og prenatalt dentin ligger i tilslutning til denne, under emaljedentingrensen $(\mathrm{EMJ}) . \mathrm{P}=$ pulpakammeret. hovedtyper: biomarkører for eksponering, effekt og følsomhet [24]. Biomarkører for eksponering gir oss informasjon om opptaket av elementer/forbindelser i kroppen mens de to andre typene biomarkørere gir informasjon om henholdsvis effekten og individets følsomhet overfor disse. Melketenner brukes typisk som biomarkører for eksponering, idet man måler tilstedeværelsen eller konsentrasjonen av sporelementer i vevet som en markør for individets eksponeringesgrad. Av definisjonen over, vil de målte konsentrasjonene av sporelementer eller kjemikalier i seg selv være biomarkørene. I litteraturen er det gjerne det analyserte vevet som benevnes som en biomarkør, underforstått dets konsentrasjoner av de målte elementene. Eksempler på vev og kroppsvæsker som benyttes som biomarkører for eksponering er blod, urin, saliva, hår, negler, bein og tenner. Alle disse vevene har sine fordeler og begrensninger når det gjelder egnetheten til å kartlegge kroppens interne miljø [25]. For eksempel viser blykonsentrasjonen i blod, med en halveringstid på ca 40 dager, den pågående eksponeringen overfor elementet, mens konsentrasjonen i beinvev, med en halveringstid på 10-30 år, viser den kumulative eksponeringen [26].

\section{TENNER SOM BIOMARKØRER FOR EKSPONERING}

Tannvev gjennomgår ikke remodellering etter at tannen er ferdigdannet, slik tilfellet er for beinvev [27]. Elementer som er bygget inn i vevet under tanndannelsen 
blir stort sett værende der og representerer dermed opptaket av disse elementene i tanndannelsesperioden. Fordi tennene vokser lagvis etter et kjent mønster og avsetter vekstlinjer i vevet [28], er det mulig å måle innhold av stoffer på tvers av vekstlinjene og dermed registrere eksponeringer over et lengre tidsrom. I melketennene gjør neonatallinjen det mulig å skille mellom pre- og postnatalt tannvev som så kan måles for elementinnhold ved hjelp av avanserte analysemetoder [29].

Tennenes hardvev har vist seg egnet som biomarkører for en rekke sporelementer, både essensielle og toksiske. De bensøkende elementene, som sink, bly og strontium, tar kalsium sin plass i hydroxyapatitten og danner stabile bindinger i det mineraliserte tannvevet [30]. Tennenes høye mineralinnhold og lave grad av elementutveksling gjør dem spesielt egnet som biomarkører for de bensøkende elementene. Egenskaper som gjør melketenner egnet som biomarkører er listet opp i Boks 1.

\section{METODER FOR ANALYSER AV SPORELEMENTER I MELKETENNER}

En rekke forskjellige metoder brukes ved kjemisk analyse av melketenner, avhengig av hvilke elementer eller kjemiske forbindelser man ønsker å undersøke. Tidligere var det mest vanlig å løse hele tannen eller pulveriserte deler av tannvevet i syre for kjemisk analyse [13,31]. Da registrerer man det kumulative innholdet av de analyserte sporelementene i tannen. Nå kan man, ved hjelp av mer avanserte teknikker, ta serier av prøver på slipesnitt av tannen på tvers av vekstlinjene [29,32]. Etter registrering av neonatallinjen (Figur 2), kan melketannen analyseres for sporelementinnhold i tannvev dannet før og etter fødselen, for å kartlegge variasjoner i elementinnholdet [6,33]. Denne metoden er også mindre destruktiv idet bare en mindre del av tannen brukes i analysen. Resten kan bevares til eventuelle senere studier.

Tannvevet er ikke homogent. Elementinnholdet varierer mellom emalje, dentin og sekundærdentin og også innen de forskjellige vevstypene. Man finner også

Boks 1. Melketenners egnethet som biomarkører.

- Det eneste stabile vevet, dannet på fosterstadiet og $\mathrm{i}$ tidlig barndom, som er tilgjengelig for analyse i stor skala på et senere tidspunkt.

- Dannes lagvis etter et kjent mønste med en markert vekstlinje omkring fødselen.

- Felles naturlig og er tilgjengelige uten fysiske inngrep.

- Relativt lave kostnader forbundet med innsamling og oppbevaring.

- Har tilnærmet ubegrenset lagringstid i tørr tilstand ved normal temperatur. variasjoner i elementinnhold mellom de forskjellige tanntyper innen samme melketannsett $[33,34]$. Dette kan blant annet forklares med at tanndannelsesperioden for de forskjellige tanntypene ikke er helt overlappende (Figur 1). Hvilke tanntyper og tannvev som blir brukt i melketannsanalyser varierer. I noen studier er bare en tanntype benyttet, $\mathrm{i}$ andre er flere typer brukt [31]. Noen har analysert emalje, andre dentin, rotdentin, rotsement eller hele tannen. Dette gjør sammenligning mellom studier vanskelig. I en studie der 1200 norske melketenner ble analysert, fant man signifikant høyere konsentrasjoner av bly, kvikksølv og sink i tenner med karies sammenlignet med tenner uten karies, samt at konsentrasjonen av de samme elementene varierte med tanntype [34].

Selv om de kjemiske analysemetodene er i stadig utvikling og nye kommer til, er det fremdeles begrensninger forbundet med disse. Det er fortsatt en mangel på tilfredsstillende referansematerialer for mineralisert vev til bruk i kjemiske analyser av en rekke sporelementer [33,35]. Utvikling av solide referansematerialer er dermed en forutsetning for å oppnå høyere grad av nøyaktighet ved analyser av disse elementene i tannvev.

\section{BLY OG ANDRE SPORELEMENTER I MELKETENNER}

Bly er det sporelementet som har vært mest studert $\mathrm{i}$ melketannsvev. En studie utført i USA i 1962 sammenlignet blykonsentrasjonen i melketenner fra en gruppe barn som var døde på grunn av blyforgiftning, en gruppe barn som overlevde etter blyforgiftning, samt en kontrollgruppe med barn uten kjent eksponering [36]. Blykonsentrasjonen i tenner fra de blyforgiftede barna var åtte til ti ganger høyere enn hos kontrollgruppen. I studier fra 1970-tallet og frem til i dag er konsentrasjonen av bly i melketenner blitt brukt for å kartlegge miljøeksponering hos barn, for eksempel i områder nær forurensende industri og områder med tett biltrafikk [12,37,38]. Resultater fra to landsomfattende tverrsnittsundersøkelser i Norge, utført på 1970og 1990-tallet, viste at blykonsentrasjonen i melketenner var halvert i løpet av de 20 årene mellom de to undersøkelsene [13]. Over 2700 melketenner fra 58 forskjellige kommuner i landet ble analysert. Resultatene korresponderer med nedgangen i blyforurensning i Norge i dette tidsrommet.

Melketenner er også blitt brukt for å kartlegge virkningen av bly på barnehelsen, med særlig fokus på nevrofysiologiske forhold $[39,40]$. Det er blitt påvist signifikante korrelasjoner mellom forhøyede blykonsentrasjoner i melketenner og lave skår på en rekke nevropsykologiske tester og IQ-tester [16,18].

En rekke andre sporelementer er også blitt analysert i melketannsvev, både toksiske og essensielle [5,33, 41-44]. Brown et al [19] analyserte sporelementer i melketenner fra en gruppe ugandiske og en gruppe britiske barn. Gruppen av ugandiske barn hadde signifi- 
kant lavere verdier av sink, samt signifikant høyere verdier av blant annet strontium og barium, mens aluminium, kobber, magnesium, bly og uran ikke viste signifikante forskjeller mellom de to gruppene. Det ble konkludert at det fysiske miljø og ernæring påvirker elementinnholdet $\mathrm{i}$ tannvev.

Melketenner har vært brukt som biomarkører for eksponering overfor miljøgifter i mer enn 50 år. Metoder for blyanalyser av mineralisert tannvev er vel dokumentert, og et terskelnivå for påvisbar skadelig eksponering er blitt foreslått [16]. For andre elementer er man ikke kommet så langt, men det arbeides blant annet med metodeutvikling for bruk av melketenner som biomarkør for manganeksponering [43]. Mangan har nevrotoksisk potensiale og er kommet i søkelyset fordi det brukes som antibankemiddel i bensin, som erstatning for bly. Dette vil føre til en økning av mangan i miljøet, med ukjente konsekvenser.

\section{RADIOAKTIVE ISOTOPER}

Melketenner er blitt brukt i kartlegging av eksponering overfor radioaktive isotoper etter utslipp fra kjernekraftverk og kjernefysiske prøvesprengninger [45-47]. En undersøkelse publisert i 2003 viste at konsentrasjonen av radioaktivt strontium (Sr-90) i over 2000 undersøkte melketenner fra 5 stater i USA, økte uventet hos barn født sent på 1990-tallet i forhold til barn født på 1980-tallet. Barn som bodde nær kjernekraftverk viste de høyeste konsentrasjonene [48]. I en retrospektiv case-control-studie, publisert i USA i 2010, ble konsentrasjonen av Sr-90 i 97 melketenner fra personer født mellom 1959 og 1961 og som senere ble diagnostisert med kreft, sammenlignet med tilsvarende konsentrasjoner i 194 melketenner fra en matchende kontrollgruppe av friske personer [47]. Personer i testgruppen som var døde som følge av kreft hadde signifikant høyere gjennomsnittlig nivå av Sr-90 i tennene enn kontrollgruppen. I England ble det funnet høyere konsentrasjoner av plutonium i melketenner fra barn bosatt nær Sellafield i forhold til barn bosatt i lenger avstand fra dette gjenvinningsanlegget for radioaktive materialer [45]. I en studie fra Sveits publisert i 2006 fant man derimot ingen økning i Sr-90 i melketenner fra barn bosatt nær kjernekraftverk på 1990-tallet [49]. Slik kan melketenner brukes til å overvåke miljøet for skadelige stoffer.

\section{UTVIKLINGSDEFEKTER I TANNVEV}

Utviklingsdefekter kan observeres i melketenner både som hypoplasier og som hypomineraliserte områder i vevet [50,51]. Årsaken til disse forandringene er ikke fullstendig klarlagt, men underernæring, sykdomstilstander, prematur fødsel og eksponering overfor miljøgifter er foreslått $[10,11,52]$. Utviklingsdefekter på grunn av forhøyet eksponering overfor fluor er veldokumentert [53], men også organiske miljøgifter kan påvirke tanndannelsen. I en studie utført i Slovakia i
2007 ble effekten av langvarig eksponering for polyklorerte bifenyler (PCB) på dental utvikling undersøkt [10]. Permanente tenner og melketenner fra 432 barn på 8 og 9 år, bosatt i et kjent PCB-kontaminert område, ble undersøkt for morfologiske avvik. Det ble funnet en dose-respons-sammenheng mellom utviklingsdefekter i emalje i de permanente tennene og grad av PCB-eksponering. Data fra melketennene viste samme tendens, men funnene var ikke statistisk signifikante. Metoder for kjemisk analyse av organiske miljøgifter i mineralisert tannvev er noe man per i dag ikke finner tilgjengelig.

\section{MELKETENNER I PROSPEKTIV EPIDEMIOLOGISK FORSKNING}

Studier der melketenner inngår som biomarkør, har ofte vært utformet som tverrsnittsundersøkelser [13], men mange longitudinelle studier og studier med retrospektivt design er også blitt publisert [54,55,47]. Et stort antall longitudinelle prospektive kohort-studier av mor og barns helse pågår nå rundt om i Europa [5658]. Den norske mor og barnundersøkelsen (MoBa) [56] er en stor og omfattende slik kohort-studie som følger mer enn 100000 barn fra fosterstadiet og gjennom oppveksten [59]. Det overordnede mål er å øke kunnskapen om årsaker til sykdom og helse samt øke mulighetene for bedre forebygging og behandling. Undersøkelsen bygger på besvarte spørreskjema under graviditeten og i barnets oppvekst, samt biologisk materiale fra mor, far og barn [60]. Det er også etablert en biobank for melketenner fra barna i undersøkelsen [61]. Det er planlagt at forskere med aktuelle problemstillinger kan søke om å få hente utvalg av tenner fra populasjoner som skal studeres, samt tenner fra matchende kontrollgrupper, sammen med aktuelle svar fra spørreskjema og eventuelle andre biologiske prøver som er tilgjengelige. Resultater fra melketannsanalyser vil kunne være med på å avdekke kausale årsaker til tilstander eller sykdomsutvikling hos barna. Denne kunnskapen kan så brukes i planlegging av forebyggende tiltak (Figur 3). I en tilsvarende kohort-studie som pågår i England, the Avon Longitudinal Study of Parent and Child (ALSPAC) [57], samles det også inn melketenner.

Til tross for at melketenner har vært benyttet i epidemiologisk forskning imer enn 50 år, har mulighetene til å påvise årsakssammenhenger mellom eksponering og sykdom vært begrenset, blant annet på grunn av studiedesign. Spesielt gjelder dette tverrsnittsundersøkelsene, ettersom de alene ikke vil kunne fastslå kausalitet for sykdom og derfor har lavere verdi i forhold til prospektive studier når det gjelder å finne årsakssammenhenger. I hvilken grad melketenner vil komme til nytte som biomarkører i de store prospektive studiene, MoBa og ALSPAC, vil være avhengig av at tilstrekkelig mange tenner samles inn, og at de eksisterende metodene for kjemiske analyser videreutvikles. Potensialet er i alle fall stort på grunn av tannvevets 
unike struktur som gjør det mulig å ta prøver som representerer eksponeringer over et lengre tidsinterval i barnets utvikling, både pre- og postnatalt. Videre er tannvev så stabilt at det har en nærmest ubegrenset holdbarhet og vil dermed være tilgjengelig for analyser langt inn $\mathrm{i}$ fremtiden når nye problemstillinger blir utformet, og forbedrede eller nye analysemetoder blir tilgjengelige.

\section{PÅVIRKNING}

UTFALL

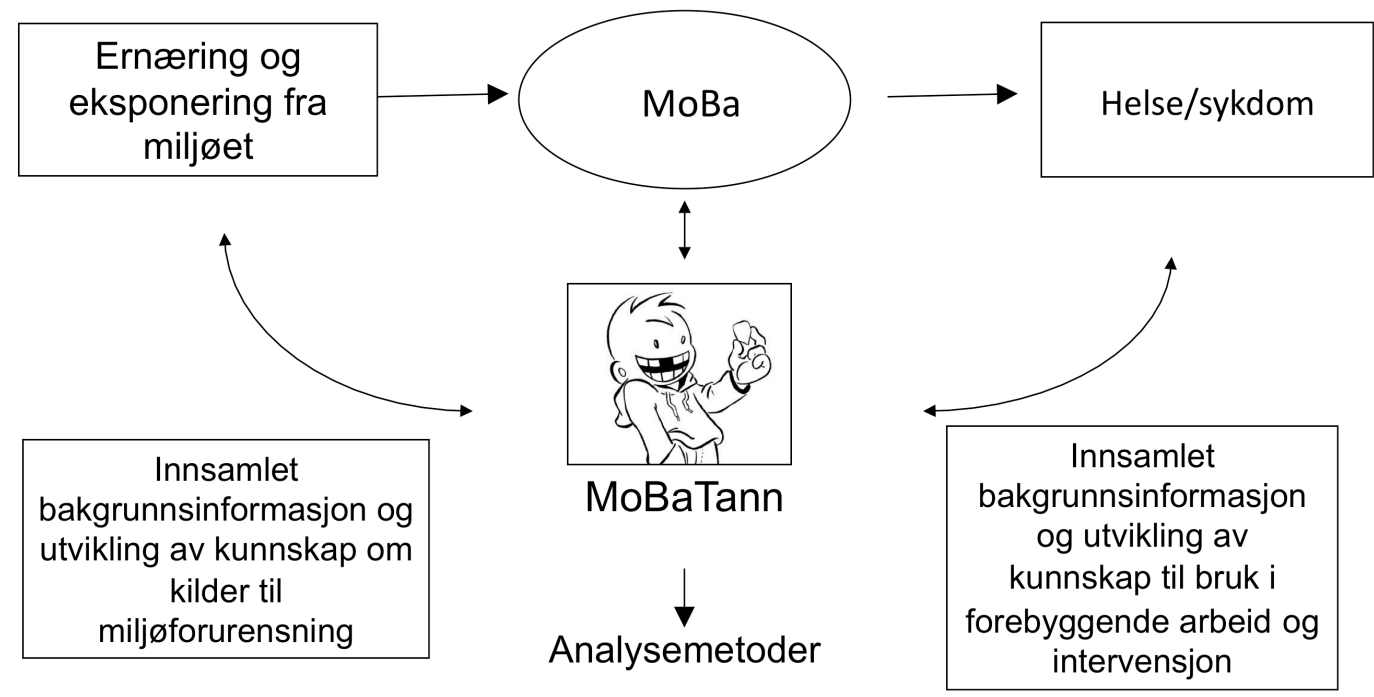

Figur 3. Skjematisk fremstilling av hvordan man planlegger at biobanken for felte melketenner innen Den norske mor og barn-undersøkelsen skal gi ny kunnskap om sammenhenger mellom eksponering og helsetilstand, og hvordan dette kan benyttes i forebyggende arbeid.

\section{REFERANSER}

1. Wigle DT, Arbucle TE, Turner MC, Berube A, Yang Q, Liu S, Krewski D. Epidemiologic evidence of relationships between reproductive and child health outcomes and environmental chemical contaminants. $J$ Toxicol Environ Health, Part B 2008; 11 (5-6): 373-517.

2. Bearer CF. How are children different from adults? Environ Health Perspect 1995; 103 (Suppl 6): 7-12.

3. Barker DJ, Osmond C, Kajantie E, Eriksson JG. Growth and chronic disease: findings in the Helsinki Birth Cohort. Ann Hum Biol 2009; 36 (5): 445-58.

4. Jones R. The importance of biological samples in longitudinal birth cohort studies. Paediatr Perinat Epidemiol 2009; 23 (Suppl 1): 93-102.

5. dela Cruz GG, Rozier RG, Bawden JW. Fluoride concentration in dentin of exfoliated primary teeth as a biomarker for cumulative fluoride exposure. Caries Res 2008; 42 (6): 419-28.

6. Ericson JE. Enamel lead biomarker for prenatal exposure assessment. Environ Res 2001; 87 (3): 136-40.

7. Dolphin AE, Goodman AH. Maternal diets, nutritional status, and zinc in contemporary Mexican infants' teeth: Implications for reconstructing paleodiets. Am J Phys Anthropol 2009; 140 (3): 399-409.

8. Sharon IM. The significance of teeth in pollution detection. Perspect Biol Med 1988; 32: 124-31.

9. Dean MC, Scandrett AE. The relation between long-period incremental markings in dentine and daily crossstriations in enamel in human teeth. Arch Oral Biol 1996; 41 (3): 233-41.

10. Jan J, Sovcikova E, Kocan A, Wsolova L, Trnovec T. Developmental dental defects in children exposed to PCBs in eastern Slovakia. Chemosphere 2007; 67 (9): 350-54.

11. Seow WK, Young WG, Tsang AK, Daley T. A study of primary dental enamel from preterm and full-term children using light and scanning electron microscopy. Pediatr Dent 2005; 27 (5): 374-79.

12. Ewers U, Turfeld M, Freier I, Hofstetter I, Stemmann G, Brockhaus A. Levels of lead and cadmium in milk teeth of children from Stolberg and some other cities of West-Germany: chronological trend 1968-1993. Zbl Hyg 1996; 198: 318-30.

13. Tvinnereim HM, Eide R, Riise T, Wesenberg GR, Fosse G, Steinnes E. Lead in primary teeth from Norway: changes in lead levels from the 1970s to the 1990s. Sci Total Environ 1997; 207 (2-3): 165-77. 
14. Hernandez-Guerrero JC, Jimenez-Farfan MD, Belmont R, Ledesma-Montes C, Baez A. Lead levels in primary teeth of children living in Mexico City. Int J Paed Dent 2004; 14 (3): 175-81.

15. Tvinnereim HM, Fantaye W, Isrenn R, Bjorvatn K, Melaku Z, Teklehaimanot R. Lead levels in primary teeth in children from urban and rural areas in Ethiopia. Ethiop Med J 2011; 49 (1): 61-6.

16. Pocock SJ, Smith M, Baghurst P. Environmental lead and children's intelligence: a systematic review of the epidemiological evidence. BMJ 1994; 309: 1189-97.

17. Omar M, Ibrahim M, Assem H, Moustafa Y, Battah F. Teeth and blood lead levels in Egyptian schoolchildren: relationship to health effects. J Appl Toxicol 2001; 21 (4): 349-52.

18. Marcus DK, Fulton JJ, Clarke EJ. Lead and conduct problems: a meta-analysis. J Clin Child Adolesc Psychol 2010; 39 (2): 234-41.

19. Brown CJ, Chenery SR, Smith B, Mason C, Tomkins A, Roberts GJ, Sserunjogi L, Tiberindwa JV. Environmental influences on the trace element content of teeth - implications for disease and nutritional status. Arch Oral Biol 2004; 49 (9): 705-17.

20. Berkovitz B, Holland G, Moxham M. Oral Anatomy, Histology and Embyology, 4th edn. London: Mosby, 2009.

21. Schour I, Massler M. The development of human dentition. J Am Dent Assoc 1941; 28: 1153-60.

22. Sabel N, Johansson C, Kuhnisch J, Robertson A, Steiniger F, Noren JG, Klingberg G, Nietzsche S. Neonatal lines in the enamel of primary teeth - a morphological and scanning electron microscopic investigation. Arch Oral Biol 2008; 53 (10): 954-63.

23. National Center for Biotechnology Information. http://www.ncbi.nlm.nih.gov/mesh/68015415 (avlest 29.10.10).

24. Grandjean P. Biomarkers in epidemiology. Clin Chem 1995; 41 (12B) 1800-3.

25. Jones R, Golding J. Choosing the types of biological sample to collect in longitudinal birth cohort studies. Paediatr Perinat Epidemiol 2009; 23 (Suppl 1): 103-13.

26. Barbosa F, Jr, Tanus-Santos JE, Gerlach RF, Parsons PJ. A critical review of biomarkers used for monitoring human exposure to lead: advantages, limitations, and future needs. Environ Health Perspect 2005; 113 (12): 1669-74.

27. Steenhout A. Kinetics of lead storage in teeth and bones: An epidemiological approach. Arch Environ Health 1982; 37: 224-30.

28. Birch W, Dean C. Rates of enamel formation in human deciduous teeth. Front Oral Biol 2009; 13: 116-20.

29. Arora M, Chan SW, Kennedy BJ, Sharma A, Crisante D, Walker DM. Spatial distribution of lead in human primary teeth as a biomarker of pre- and neonatal lead exposure. Sci Total Environ 2006; 371 (1-3): 55-62.

30. Blumenthal NC. The in vitro uptake of trace elements by hydroxyapatite. In: Priest ND, Van De Vyver FL (eds). Trace metals and fluoride in bones and teeth. Boca Raton: CRC Press, 1990; 307-14.

31. Fergusson JE, Purchase NG. The analysis and levels of lead in human teeth: a review. Environ Pollut 1987; 46: $11-44$

32. Kang D, Amarasiriwardena D, Goodman AH. Application of laser ablation-inductively coupled plasma-mass spectrometry (LA-ICP-MS) to investigate trace metal spatial distributions in human tooth enamel and dentine growth layers and pulp. Anal Bioanal Chem 2004; 378 (6): 1608-15.

33. Dolphin AE, Goodman AH, Amarasiriwardena DD. Variation in elemental intensities among teeth and between pre- and postnatal regions of enamel. Am J Phys Anthropol 2005; 128 (4): 878-88.

34. Tvinnereim HM, Eide R, Riise T. Heavy metals in human primary teeth: some factors influencing the metal concentrations. Sci Total Environ 2000; 255 (1-3): 21-7.

35. Bellotto VR, Miekeley N. Improvements in calibration procedures for the quantitative determination of trace elements in carbonate material (mussel shells) by laser ablation ICP-MS. Fresenius J Anal Chem 2000; 367 (7): $635-40$.

36. Altshuller LF, Halak DB, Landing BH, Kehoe RA. Deciduous teeth as an index of body burden of lead. $J$ Pediatr 1962; 60: 224-9.

37. Lyngbye T, Hansen ON, Grandjean P. Predictors of tooth-lead level with special reference to traffic - A study of lead-exposure in children. Int Arch Occup Environ Health 1990; 62: 417-22.

38. Hegde S, Sridhar M, Bolar DR, Bhaskar SA, Sanghavi MB. Relating tooth- and bloodlead levels in children residing near a zinc-lead smelter in India. Int J Paediatr Dent 2010; 20 (3): 186-92.

39. Hansen ON, Trillingsgaard A, Beese I, Lyngbye T, Grandjean P. A neuropsychological study of children with elevated dentine lead level: Assessment of the effect of lead in different socio-economic groups. Neurotoxicol Teratol 1989; 11: 205-13.

40. McMichael AJ, Baghurst PA, Vimpani GV, Wigg NR, Robertson EF, Tong SL. Tooth lead levels and IQ in school-age children: The Port Pirie cohort study. Am J Epidemiol 1994; 140: 489-99.

41. Tvinnereim HM, Eide R, Fosse G, Wesenberg GR, Szøke J, Banoczy J. Trace elements in primary teeth from six areas in Hungary. Int J Environ Stud 1996; 50: 267-75. 
42. Tvinnereim HM, Eide R, Riise T, Fosse G, Wesenberg GR. Zinc in primary teeth from children in Norway. Sci Total Environ 1999; 226 (2-3): 201-12.

43. Ericson JE, Rinderknecht A, Gonzalez EJ, Crinella FM, Kleinman MT. Measurements of manganese with respect to calcium in histological enamel cross sections: toward a new manganese biomarker. Environ Res 2001; 86 (1): 46-50.

44. Fischer A, Kwapulinski J, Wiechula D, Fischer T, Loska M. The occurrence of copper in deciduous teeth of girls and boys living in Upper Silesian Industry Region (Southern Poland). Sci Total Environ 2008; 389 (2-3): 315-9.

45. O'Donnell RG, Mitchell PI, Priest ND, Strange L, Fox A, Henshaw DL, Long SC. Variations in the concentration of plutonium, strontium-90 and total alpha-emitters in human teeth collected within the British Isles. Sci Total Environ 1997; 201 (3): 235-43.

46. Gould JM, Sternglass EJ, Sherman JD, Brown J, McDonnell W, Mangano JJ. Strontium-90 in deciduous teeth as a factor in early childhood cancer. Int J Health Serv 2000; 30 (3): 515-39.

47. Mangano JJ, Sherman JD. Elevated in vivo strontium-90 from nuclear weapons test fallout among cancer decedents: a case-control study of deciduous teeth. Int J Health Serv 2011; 41 (1): 137-58.

48. Mangano JJ, Gould JM, Sternglass EJ, Sherman JD, McDonnell W. An unexpected rise in strontium-90 in US deciduous teeth in the 1990s. Sci Total Environ 2003; 317 (1-3): 37-51.

49. Froidevaux P, Geering JJ, Valley JF. ${ }^{90} \mathrm{Sr}$ in deciduous teeth from 1950 to 2002: the Swiss experience. Sci Total Environ 2006; 367 (2-3): 596-605.

50. Slayton RL, Warren JJ, Kanellis MJ, Levy SM, Islam M. Prevalence of enamel hypoplasia and isolated opacities in the primary dentition. Pediatr Dent 2001; 23 (1): 32-6.

51. Franco KM, Line SR, Moura-Ribeiro MV. Prenatal and neonatal variables associated with enamel hypoplasia in deciduous teeth in low birth weight preterm infants. J Appl Oral Sci 2007; 15 (6): 518-23.

52. Norén JG, Gillberg C. Mineralization disturbances in the deciduous teeth of children with so called minimal brain dysfunction. Swed Dent J 1987; 11 (1-2): 37-43.

53. Aoba T, Fejerskov O. Dental fluorosis: chemistry and biology. Crit Rev Oral Biol Med 2002; 13 (2): 155-70.

54. Needleman HL, Schell A, Bellinger D, Leviton A, Allred EN. The long-term effect of exposure to low doses of lead in childhood: An 11-years following-up report. N Engl J Med 1990; 322 (2): 83-8.

55. Kim R, Hu H, Rotnitzky A, Bellinger D, Needleman H. A longitudinal study of chronic lead exposure and physical growth in Boston children. Environ Health Perspect 1995; 103: 952-57.

56. Magnus P, Irgens LM, Haug K, Nystad W, Skjaerven R, Stoltenberg C. Cohort profile: The Norwegian Mother and Child Cohort Study (MoBa). Int J Epidemiol 2006; 35 (5): 1146-50.

57. Golding J, Pembrey M, Jones R. ALSPAC - the Avon Longitudinal Study of Parents and Children. I. Study methodology. Paediatr Perinat Epidemiol 2001; 15 (1): 74-87.

58. Polanska K, Hanke W, Jurewicz J, Sobala W, Madsen C, Nafstad P, Magnus P. Polish mother and child cohort study (REPRO_PL) - Methodology of follow-up of the children. Int J Occup Med Environ Health 2011; 24 (4): 391-8.

59. Folkehelseinstituttet: http://www.fhi.no/morogbarn (avlest 10.10. 2011).

60. Rønningen KS, Paltiel L, Meltzer HM, Nordhagen R, Lie KK, Hovengen R, Haugen M, Nystad W, Hoppin JA, Magnus P. The biobank of the Norwegian Mother and Child Cohort Study: a resource for the next 100 years. Eur J Epidemiol 2006; 21 (8): 619-25.

61. Tvinnereim HM, Lygre GB, Schreuder P, Haug K, Klock KS. A biobank of primary teeth within the Norwegian Mother and Child Cohort Study (MoBa): a resource for the future. Pediatr Perinat Epidemiol 2012; 26: 264-71. 